\title{
Students' Peer Assessment and Perception on ICT-based Instructional Media
}

\author{
Rusma Noortyani \\ Department of Language Education and Indonesian Literature \\ Faculty of Teacher Training and Education, Universitas Lambung Mangkurat \\ Banjarmasin, Indonesia \\ rusmanoortyani@gmail.com
}

\begin{abstract}
Instructional media play an important role in supporting teaching and learning process, especially in the era of ICT nowadays. The use of the media needs a careful preparation, planning as well as effective implementation in order that the media would optimally enhance the teaching and learning process. This study reported the result of a training which was given to the students who took Instructional Media and ICT course on how to design and apply PowerPoint presentation and video appropriately in teaching and learning process. More particularly, the problem of the study was addressed to investigate the students' peer assessment and perception on the use of PowerPoint presentation and video as ICT-based instructional media. This study used descriptive explanatory design and employed questionnaires as the instrument. After the students joined the training, they were asked to utilize the media in teaching Bahasa Indonesia Subject and subsequently fill in questionnaires to give peer assessment on their peers' performance in utilizing the media in the teaching and learning process. They also stated their perception in the given questionnaire. The results of the questionnaire were analyzed by using descriptive statistics. The results showed that the students generally gave positive peer assessment to their peers' performance. This study also suggested that the training helped them in designing and applying the media appropriately to support the learning objective. Training in using instructional media is considered beneficial for the optimal implementation of the media in the classroom context.
\end{abstract}

Keywords -Instructional Media, Peer Assessment, Perception, Powerpoint Presentation, Video

\section{INTRODUCTION}

Instructional media have been considered as pivotal factor in helping teachers to conduct on optimal teaching and learning process. The advancement of technology has made instructional media more sophisticated and in turn, boost their capability in optimizing the teaching and learning process. By utilizing ICT-based instructional media, the delivery of learning material will be clearer and interesting, so students can grasp the material easily. The clear delivery of learning material is more likely since instructional media, especially in the form of visual aids, can help students to develop a holistic understanding that words cannot convey [1]. Delivering learning material using instructional media would help students to get simple and meaningful display of the complex concepts and process as well as restructure information from the material easily [2], [3][4].

ICT-based Instructional media assist not only the delivery of learning material, but they also assist to create positive learning experience for students. Ref [5] assert that the use of instructional media encourages teachers to use various teaching methods without merely using verbal communication. Further, students can do more activities by using the media since they do not only listen to their teacher, but they can also observe, perform, and demonstrate [5]. Instructional media play important role in making the learning activities interesting and interactive; therefore, students will be more motivated to participate in the activities [6].

A number of studies have been conducted to give empirical data about the benefits of instructional media from the viewpoint of students. Reference [7] conducted survey which investigated the perceptions and experiences of students from seventh, eighth and ninth grade in utilizing the multimedia technology during their summer technology camp. Based on the results of the survey, the students perceived that the use of multimedia technology makes their learning more fun and easier. It has also boosted their motivation and participation in the learning process. The similar result is also revealed by [8] in that the students gave strong support toward the use of multimedia technology in their learning activities. More particularly, [1] investigated students' and teachers' attitudes toward the usage of visual aids, which were PowerPoint presentation, Prezi presentation and video, in teaching and learning process. The students in [1] study showed positive attitude toward the use of the visual aids. The students considered the visual aids beneficial to increase their participation in the classroom, their interest and motivation. Ref. [1] study also revealed that incorporating videos and presentations to bring the real world as the contextualization of the language content to the classroom has made the learning activities more meaningful for the students. Thus, the use of ICT-based instructional media contributes positively to students' learning experience. 
In addition to students' positive perception on the use of ICT-based instructional media, teachers were also found to have also positive perception towards the utilization of instructional media in classrooms [9], [10]. The factors which influence the teachers' perception toward the use of instructional media are the availability of media technology equipment and appropriate materials, teachers' knowledge on the media, and proper teacher training [10]. Unfortunately, in spite of teachers' positive perception, the study conducted by [1] and [10] showed that the teachers in the settings of their studies infrequently use the available multimedia devices. Reference [1] further mentioned that in reality the use of instructional media is infrequent although teachers in her study consider preparing visuals as instructional media as their regular job. Thus, it can be inferred that the influential factors in the use of instructional media which should be more taken into account are teachers' knowledge on the media and proper teacher training. Teachers might show positive perception on the use of instructional media, yet they need knowledge, ability, and skill to put the use of instructional media into real practice.

The lack of knowledge, ability and skill may hinder teachers to make use of ICT-based instructional media. Ref. [1] pointed up that $67 \%$ of teachers in her study stated that they have not received appropriate training on how to use instructional media in the classrooms and this finding might explain why the ICT-based instructional media, including presentation and video, in the setting of her study were infrequently used. Moreover, [11] found that there was significant difference in the perception between trained teachers who were exposed to instructional technology while at college and untrained teachers who were not. Reference [11] concluded that pre-service training affects the teachers' perception. Regarding this case, [9] suggest that "teachers need to motivate themselves on the significance of media use in classrooms and also to undertake in-service courses on ICT utilization in teaching and learning". Besides in-service courses, there should be a training for students especially teacher-to-be students on integrating ICT-based instructional media into their teaching and learning practices [8].

The importance of ICT-based instructional media, the lack of teachers' knowledge and ability in utilizing the media, as well as the need of training on integrating ICT-based instructional media in teaching practice as previously outlined underpinned the present study which focused on the use of ICT-based instructional media by students who are taking educational degree and are preparing themselves to be teachers in their future career. To anticipate the hindering factors and to equip the students with sufficient knowledge and experience, a training on the utilization of ICT-based instructional media in the form of PowerPoint presentation and video was conducted. This present study aimed to investigate the students' peer assessment and perception on the use of PowerPoint presentation and video in the real practice after they have followed the training. Peer-assessment was considered as potential assistance in the training since peer assessment can provide feedback and reflection on what to be improved from students' teaching practice in implementing the instructional media. Peer assessment has been considered beneficial in promoting student learning, enhancing student understanding on the work they should make, and improving student performance [12][13]. A number of studies have shown positive perception of students with regard to peer assessment [14][15].

The research questions were formulated as follows:

1. How is the students' peer assessment on the use of PowerPoint presentation and video in teaching practice?

2. How is the students' perception on the use of PowerPoint presentation and video in teaching practice after the training?

\section{METHOD}

In this study, the respondents were 27 students who took Instructional Media and ICT course in Teacher Training and Education Faculty, Lambung Mangkurat University, Banjarmasin, Indonesia. There were 3 male students and 24 female students.

The training was conducted as the specialized part of the course. The training included direct instruction and modelling, observation, presentation and discussion of the observation result, preparation of PowerPoint presentation and video as the media, micro-teaching practice using the media, and schoolbased teaching practice. The training started with direct instruction by the researcher who was the lecturer of the course. The direct instruction covered the importance of instructional media in language teaching, the types of the media, and the use of PowerPoint presentation and video in language teaching. The direct instruction was also complemented with modelling of the use of PowerPoint and Video in teaching particular material in Bahasa Indonesia subject. The materials used in the training were Media Pendidikan written by [6] and Instructional Technology and Media for Learning.

At the observation phase, the students in groups were assigned to observe the use of the media in teaching Bahasa Indonesia subject in certain schools and make the observation report. By referring to the theories and the observation result, the students were instructed to prepare a teaching scenario and their PowerPoint presentation as well as video to be used in teaching a certain material in Bahasa Indonesia subject. The sample materials the students chose were exposition text, writing advertisement, writing a review, poetry, expressing suggestion and criticism, as well as intrinsic and extrinsic features of short stories. 
The subsequent phase was presenting and discussing the results of the students' observation. The students were also required to show their teaching scenario, media and the teaching material to get feedback from their peers and the lecturer. At this phase, the students discussed whether their material and media were already aligned with the goal of the instruction, the way in which pictures and visual organizers assist the students, and the strategies to optimize the use of the media.

At the next phase, the students did micro-teaching practice using the media and were given peerassessment by other students. The students had to revise their teaching scenario, the content and design of the PowerPoint presentation and video based on the given feedback in the peer-assessment form. Following the revision was the school-based teaching practice for 45 minutes in three accessible schools. The students' performance was recorded. At the end of the training, the lecturer played some samples of the video, discussed them together with the students, and asked some students to express their opinion about their teaching experience. After the training has finished, a questionnaire was administered to the students to find their perception on the use of PowerPoint presentation and video in their school-based teaching practices.

Two instruments were used in this study, namely peer assessment form and questionnaire of students' perception. Peer assessment form was adapted from media evaluation form by [6]. The form consisted of two parts, namely the way of utilizing the media and the quality of the media. The way of utilizing media covered clarity of the presentation or delivery, strategies in making use of the media and speed of presentation. The quality of PowerPoint media included the suitability with instructional objective, material arrangement, key points, comprehensibility of the slide content, readability of fonts and color, and the suitability of pictures. The quality of the video included the suitability with instructional objective, comprehensibility of the video content, visual quality and audio quality. The assessment used 5 likert-scales ranging from 'very good' to 'very poor'. The questionnaire of students' perception was adapted from [1] and [10] considering the suitability and comprehensibility of the instrument items for the purpose of this study. The classification of the scores in peer assessment was shown in Table 1.

TABLE I. THE CLASSIFICATION FOR SCORES FROM PEER

\begin{tabular}{|c|c|}
\hline \multicolumn{2}{|c|}{ ASSESSMENT } \\
\hline Index Range & Score Category \\
\hline $85-100$ & Very good \\
\hline $69-84$ & good \\
\hline $53-68$ & fair \\
\hline $37-52$ & poor \\
\hline $20-36$ & Very poor \\
\hline
\end{tabular}

\section{RESULTS AND DISCUSSION}

This study reported the result of the training on the utilization of PowerPoint presentation and video as indicated by the results of peer assessment and students' perception. The results of peer assessment comprised two parts, namely the way of utilizing the media and the quality of the media. The students' mean score for the first part was 74.62. This showed that generally the way the students utilized the media was at good category. The detailed scores can be seen in Fig. 1.

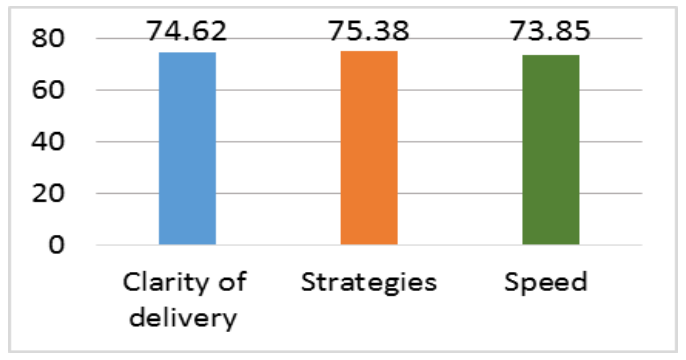

Fig. 1. Mean score of the way students utilized the media

Based on Fig. 1, the peer assessment resulted in the mean score of 74.62 for the clarity of students' delivery or presentation in utilizing the media. The mean score for the strategies in utilizing the media was 75.38, while the mean score for speed of presentation was 73.85. The highest mean score in this part was attributed to the students' strategies in utilizing the media. On the comment section of the peer assessment form, most of the students suggested that their peers explained the material using the PowerPoint presentation and gave instruction more clearly. They also suggested that their peers considered to lower the speed.

The result of peer assessment on the quality of students' PowerPoint presentation also indicated good category with the mean score of 78.9. The detailed scores for all sub-components can be seen in Fig. 2.

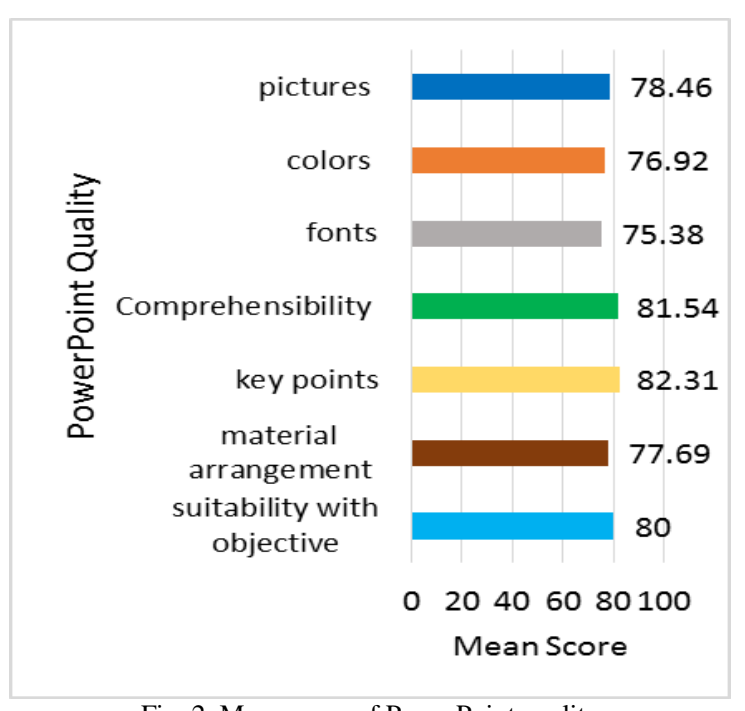

Fig. 2. Mean score of PowerPoint quality

Based on Fig. 2, the three highest mean scores were indicated on the quality of key points, 
comprehensibility of the slide content and the suitability of the content and slide use with the instructional objective, namely 82.31, 81.54, and 80, respectively. The readability of fonts obtained the lowest score, namely 75.38. This was aligned with the students' comments which highlighted the size of fonts in the students' slides. Some of the students suggested that the fonts were enlarged and given different color as an emphasis.

The peer assessment on video quality resulted in the highest mean score, namely 80.58 , which was also at good category. The detailed scores for all subcomponents can be seen in Fig. 3.

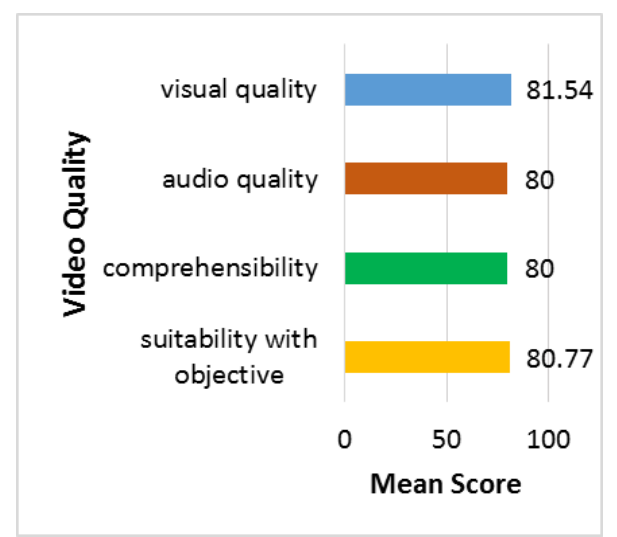

Fig. 3. Mean score of video quality

Fig. 3 showed that the highest mean score among the sub-components of video quality was indicated at visual quality, namely 81.54 . This mean score was followed by the mean score for suitability with the instructional objective, which was 80.77 . The mean scores for comprehensibility of the video content and audio quality were equal, namely 80 . These findings were aligned with the positive comments of the students in the peer assessment form.

The second major result of this study was the students' perception on the use of PowerPoint presentation and video in teaching practice. The students' perception was divided into two aspects: (1) students' interest in using ICT-based instructional media and (2) their perception on its usefulness. At the end of the questionnaire, the students were also required to give their perception on the peer assessment and the training as the additional data of this study. The results of the questionnaire showed that the students' interest in using ICT-based instructional media was quite high. Fig. 4 showed the detailed percentage of the students' response.

Based on Fig. 4, the majority of the students $(81.48 \%)$ stated that they were very interested in using ICT-based instructional media, while $18.52 \%$ of the students stated that they were fairly interested in the usage. The students explained that they selected 'very interested' option because they were aware that the media were beneficial for teaching and learning activity and the use of the media helped them in their teaching practice a lot. Some of them also mentioned that the use of PowerPoint and video has attracted their students' attention and made them motivated to pay attention to the lesson. The students who selected 'fairly interested' generally stated that they still needed to practice more in using the media.

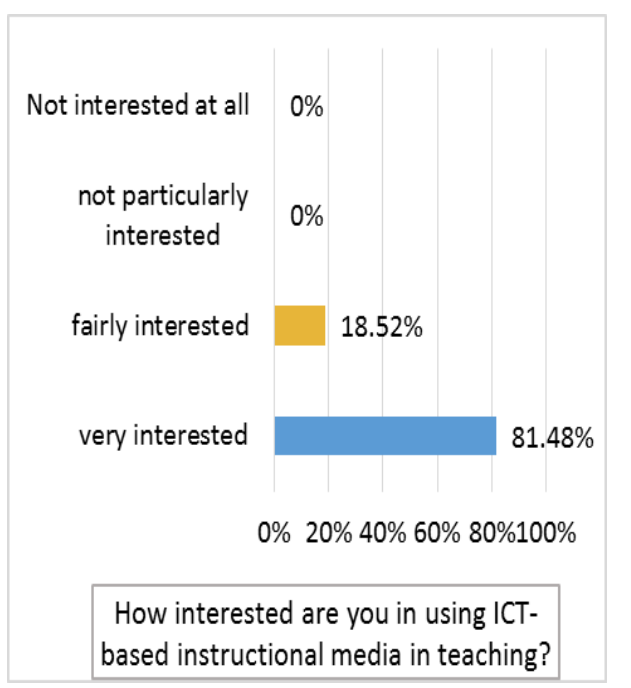

Fig. 4. Students' interest in using ict-based instructional media

The next part of the questionnaire was students' perception on the usefulness of PowerPoint and video as visual aids in ICT-based instructional media. The detailed item of this part is shown in Table 2. The term 'learners' was used to refer to the students in the school setting where the students, the respondents of this study, did their teaching practice.

TABLE II. QUESIONNAIRE ITEMS FOR STUDENTS' PERCEPTIONS ON THE USEFULLNESS OF THE MEDIA

\begin{tabular}{|l|l|}
\hline No. & \multicolumn{1}{|c|}{ Item } \\
\hline 1. & I enjoy using PowerPoint and video in teaching. \\
\hline 2. & $\begin{array}{l}\text { I am personally committed to the use of PowerPoint and } \\
\text { video in teaching. }\end{array}$ \\
\hline 3. & $\begin{array}{l}\text { I know how to use and apply PowerPoint and video in } \\
\text { language classroom. }\end{array}$ \\
\hline 4. & $\begin{array}{l}\text { I consider that the use of PowerPoint and video in the } \\
\text { language classroom may help learners to focus their attention } \\
\text { on the topic. }\end{array}$ \\
\hline 5. & $\begin{array}{l}\text { I believe that the use of PowerPoint and video in the } \\
\text { language classroom increases learners' motivation and } \\
\text { participation in the class. }\end{array}$ \\
\hline 6. & $\begin{array}{l}\text { I use visual aids (PowerPoint and Video) in my lessons to } \\
\text { support my explanations }\end{array}$ \\
\hline 7. & $\begin{array}{l}\text { Visual aids can provide learners with more than one way to } \\
\text { access information. }\end{array}$ \\
\hline 8. & $\begin{array}{l}\text { Visual aids can provide learners with sufficient variety to } \\
\text { maintain their interests. }\end{array}$ \\
\hline 9. & $\begin{array}{l}\text { I am willing to invest time and energy in providing the media } \\
\text { (i.e., through classroom preparation). }\end{array}$ \\
\hline
\end{tabular}

The results of the questionnaire showed that $18.52 \%$ of the students strongly agreed that they enjoyed using PowerPoint and video in their teaching practice, while $81.48 \%$ of the students agreed with the statement. At the second and third items, all of the students agreed that they were personally committed to 
the use of PowerPoint and video in teaching and they had the knowledge of the usage. At the fourth item, approximately half of the students $(55.56 \%)$ gave strong agreement and the other half $(44.44 \%)$ gave agreement toward the benefit of PowerPoint and video in focusing the attention of the learners in their teaching practice.

The next results showed that $48.15 \%$ of the students strongly agreed that the use of the media made the learners motivated and participated more in the learning activities, while $51.85 \%$ preferred 'agree' option. For the item indicating the support of PowerPoint and video to the explanation of the lesson, $62.96 \%$ of the students showed strong agreement and $37.04 \%$ showed their agreement. Furthermore, the majority of the students $(88.89 \%)$ strongly agreed that PowerPoint presentation and video provide the learners with more than one way to access information. Finally, for the last two items, all of the students agreed that the media could maintain the learners' interest, and they were willing to invest their time and energy in preparing the media in the future teaching practice.

The last part of the questionnaire revealed the students' perception on the peer assessment and the training wherein they have taken part. The students perceived that peer assessment was really useful for the improvement of their teaching performance and the quality of their media. They could be aware of the lack of their performance from the peer assessment. The students also regarded the training as the empowerment for their ability in using media in teaching. They asserted that they felt more self-efficacious in using PowerPoint and video in teaching after the training since they could get knowledge, model, instruction, feedback, and meaningful experience on the utilization of the media. Some of the students also stated that they needed to practice more in preparing media for teaching need since the preparation took time.

The findings of this study on peer assessment conform to the benefits of peer assessment postulated by scholars [12][13] in terms of the improvement on students' performance. Moreover, the students in this study highly valued peer assessment confirming the study by [14] and [15].

This study showed that the students had positive perception on the use of PowerPoint and video in their teaching practice. This finding is aligned with [9][1], and [10] who involved teachers as the respondents. Although the students are still at college, they have already perceived that the use of ICT-based instructional media is worth-conducting, for the media could make learners more motivated, increase learners' participation and focus learners' attention based on their teaching experience. The students' perception confirmed that the use of instructional media plays important role in affecting learners' motivation and participation positively [6]. The increased motivation and participation of learners might be influenced by the supports PowerPoint presentation and video provide in bringing the contextualization of the real world experience to classroom [1].

This study further revealed that giving a specific training on the utilization of instructional media could improve the students' self-efficacy in using the media in their teaching practice. Self-efficacy in using instructional media is necessary to solve lack of knowledge and ability as the problems hindering the implementation of instructional media in teaching practice [1][11]. It is important to note that the training enables the students to see the importance of utilizing instructional media and experienced its real use from real teaching practice. The students' experience during the whole training increased their interest in using the media. This early high interest is positive since motivation in using instructional media is prominent to actualize successful implementation of the media in teaching practice [9]. This study also confirmed that giving training could address the solution for the inadequacy of knowledge and ability in the use of instructional media as highlighted by [1]. Giving training is also one of the solutions to equip and encourage teacher-to-be students and teachers to utilize ICT-based instructional media of any kinds in classroom instructions [8][9].

\section{CONCLUSION}

Knowledge, ability, and skill in using ICT-based instructional media in teaching any subjects at any school levels have become prominent issues to be taken into account by those who intend to be teachers and practitioners. These issues need to be addressed and coped with in early teacher education. The importance of ICT-based instructional media in teaching and learning activities is already pertinent, yet actualizing the theories, knowledge, and skill in using the media into practice remains challenging. This study has revealed that a training in utilizing ICT-based instructional media in the form of PowerPoint presentation and video assists students of teacher education to prepare, plan, and apply the use of the media in teaching activities. The peer assessment in the training showed that the students had good performance in using the media in teaching practice and it gave positive impact for the improvement of the students' performance. This study also pointed up students' positive perception on the use of the media, peer assessment and the training. In a nutshell, an early specific training on utilization of ICT-based instructional media is necessary and worth-conducting to enhance students' ability in using instructional media for teaching purpose.

\section{REFERENCES}

[1] R.G. Maria, "Usage of multimedia visual aids in the English language classroom: A case study at Margarita Salas Secondary School (Majadahonda)," 2012, Retrieved from 
https://www.ucm.es/data/cont/docs/119-2015-03-17-

11.MariaRamirezGarcia2013.pdf.

[2] S. Kang, "Using visual organizers to enhance EFL instruction," ELT Journal, vol. 58, pp. 58-67, 2004.

[3] R.C. Clark and C. Lyons, Graphics for learning: Proven guidelines for planning, designing, and evaluation visuals in training materials. San Francisco, CA: Pfieffer, 2004.

[4] R. N. Carney and J. R. Levin, "Pictorial illustrations still improve students' learning from text," Educational Psychology Review, vol. 14, pp. 5-26, 2002.

[5] N. Sudjana and A. Rivai, Media pengajaran. Bandung: Sinar Baru Algesindo, 2013.

[6] A.S. Sadiman, R. Raharjo, A. Haryono, and Harjito, Media pendidikan: Pengertian, pengembangan dan pemanfaatannya. Jakarta: Pustekkom Dikbud \& PT RajaGrafindo Persada, 2014.

[7] T. Sivakumaran, K. Garcia, L. Davis, Q. Jones, J. Choi, and M. Dawson, "Student perceptions of multimedia technology integrated in classroom learning," International Journal of Humanities and Social Science, vol. 2, pp. 67-70, 2012.

[8] H.A. Liton, "Examining students' perception \& efficacy of using technology in teaching English," International Journal of Education and Information Technology, vol. 1, pp. 11-19, 2015.

[9] E. Rugut and J. Role, "Teachers and students perceptions on the utilisation of educational media in teaching and learning history and government in secondary schools in Kenya," International Journal of Science and Research (IJSR), vol. 5, pp. 1761-1768, 2016.

[10] C.H. Lee, The use of media technology in foreign language teaching and learning at university level: A study of teachers' attitudes in Korea, 1997, Retrieved from https://theses.ncl.ac.uk/dspace/bitstream/10443/292/1/Lee97.p df

[11] S. Taiwo, "Teachers' perception of the role of media in classroom teaching in secondary schools," The Turkish Online Journal of Educational Technology, vol. 8, 2009.

[12] N. Falchikov and J. Goldfinch, "Student peer assessment in higher education: A meta-analysis comparing peer and teacher marks," Review of Educational Research, vol. 70, pp. 287$322,2000$.

[13] C.P. Wheater, A.M. Langan, and P.J. Dunleavy, "Can students assess students effectively? Some insights into peerassessment," Planet, vol. 15, pp. 13-15, 2005.

[14] K. Stepanyan, R. Mather, H. Jones, and C. Lusuardi, "Student engagement with peer assessment : a review of pedagogical design and technologies," In: Advances in Web Based Learning - ICWL 2009, Lecture Notes in Computer Science, vol. 5686, pp. 367-375, 2009.

[15] G. Thomas, D. Martin, and K. Pleasant, "Using self- and peerassessment to enhance students' future-learning in higher education," Journal of University Teaching \& Learning Practice, vol. 8, pp. 1-17, 2011. 